\title{
Front Matter: Volume 6858
}

, "Front Matter: Volume 6858," Proc. SPIE 6858, Optics in Tissue Engineering and Regenerative Medicine II, 685801 (15 February 2008); doi:

10.1117/12.791309

SPIE. Event: SPIE BiOS, 2008, San Jose, California, United States 


\section{PROGRESS IN BIOMEDICAL OPTICS AND IMAGING}

Vol. 9, No. 17

\section{Optics in Tissue Engineering and Regenerative Medicine II}

Sean J. Kirkpatrick

Ruikang K. Wang

Editors

20-21 January 2008

San Jose, California, USA

Sponsored and Published by

SPIE

Volume 6858

Proceedings of SPIE, 1605-7422, v. 6858

SPIE is an international society advancing an interdisciplinary approach to the science and application of light. 
The papers included in this volume were part of the technical conference cited on the cover and title page. Papers were selected and subject to review by the editors and conference program committee. Some conference presentations may not be available for publication. The papers published in these proceedings reflect the work and thoughts of the authors and are published herein as submitted. The publisher is not responsible for the validity of the information or for any outcomes resulting from reliance thereon.

Please use the following format to cite material from this book:

Author(s), "Title of Paper," in Optics in Tissue Engineering and Regenerative Medicine II, edited by Sean J. Kirkpatrick, Ruikang K. Wang, Proceedings of SPIE Vol. 6858 (SPIE, Bellingham, WA, 2008) Article CID Number.

ISSN 1605-7422

ISBN 9780819470331

Published by

SPIE

P.O. Box 10, Bellingham, Washington 98227-0010 USA

Telephone +1 3606763290 (Pacific Time) · Fax +1 3606471445

SPIE.org

Copyright (C) 2008, Society of Photo-Optical Instrumentation Engineers.

Copying of material in this book for internal or personal use, or for the internal or personal use of specific clients, beyond the fair use provisions granted by the U.S. Copyright Law is authorized by SPIE subject to payment of copying fees. The Transactional Reporting Service base fee for this volume is $\$ 18.00$ per article (or portion thereof), which should be paid directly to the Copyright Clearance Center (CCC), 222 Rosewood Drive, Danvers, MA 01923. Payment may also be made electronically through CCC Online at copyright.com. Other copying for republication, resale, advertising or promotion, or any form of systematic or multiple reproduction of any material in this book is prohibited except with permission in writing from the publisher. The CCC fee code is 1605 $7422 / 08 / \$ 18.00$.

Printed in the United States of America.

Publication of record for individual papers is online in the SPIE Digital Library.

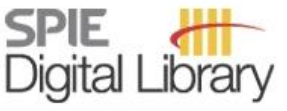

SPIEDigitallibrary.org

Paper Numbering: Proceedings of SPIE follow an e-First publication model, with papers published first online and then in print and on CD-ROM. Papers are published as they are submitted and meet publication criteria. A unique, consistent, permanent citation identifier (CID) number is assigned to each article at the time of the first publication. Utilization of CIDs allows articles to be fully citable as soon they are published online, and connects the same identifier to all online, print, and electronic versions of the publication. SPIE uses a six-digit CID article numbering system in which:

- The first four digits correspond to the SPIE volume number.

- The last two digits indicate publication order within the volume using a Base 36 numbering system employing both numerals and letters. These two-number sets start with 00, 01, 02, 03, 04 , 05, 06, 07, 08, 09, 0A, OB ... 0Z, followed by 10-1Z, 20-2Z, etc.

The CID number appears on each page of the manuscript. The complete citation is used on the first page, and an abbreviated version on subsequent pages. Numbers in the index correspond to the last two digits of the six-digit CID number. 


\section{Contents}

$\checkmark$ Conference Committee

\section{SESSION 1 MECHANICS}

685802 Spatio-temporal algorithms for processing laser speckle imaging data [6858-01]

D. D. Duncan, S. J. Kirkpatrick, Oregon Health \& Science Univ. (USA)

685803 Modeling and measurement of tissue elastic moduli using optical coherence elastography [6858-02]

X. Liang, A. L. Oldenburg, V. Crecea, S. Kalyanam, M. F. Insana, S. A. Boppart, Univ. of Illinois at Urbana-Champaign (USA)

685804 Complex flow characterisation of a porous tissue scaffold measured by Doppler optical coherence tomography [6858-03]

P. H. Tomlins, Y. Wang, B. Zhang, M. Tedaldi, P. E. Tomlins, National Physical Lab. (United Kingdom)

685805 Modification of measurement methods for evaluation of tissue-engineered cartilage function and biochemical properties using nanosecond pulsed laser [6858-04] M. Ishihara, National Defense Medical College (Japan) and Tokai Univ. School of Medicine (Japan); M. Sato, T. Kutsuna, Tokai Univ. School of Medicine (Japan); M. Ishihara, National Defense Medical College Research Institute (Japan); J. Mochida, Tokai Univ. School of Medicine (Japan); M. Kikuchi, National Defense Medical College (Japan)

685806 Monitoring the effect of mechanical stress on mesenchymal stem cell collagen production by multiphoton microscopy [6858-05]

W.-L. Chen, C.-C. Chang, L.-L. Chiou, T.-H. Li, Y. Liu, National Taiwan Univ. (Taiwan); H.-S. Lee, National Taiwan Univ. (Taiwan), National Taiwan Univ. Hospital (Taiwan), and National Taiwan Univ. College of Medicine (Taiwan); C.-Y. Dong, National Taiwan Univ. (Taiwan)

\section{SESSION 2 IMAGING I}

685809 Tissue morphology from spectral polarimetry [6858-08]

D. D. Duncan, J. C. Gladdish, B. D. Markway, Oregon Health \& Science Univ. (USA)

6858 OA Rotating orthogonal polarization imaging for tissue imaging [6858-09]

S. P. Morgan, Q. Zhu, I. M. Stockford, J. A. Crowe, Univ. of Nottingham (United Kingdom)

\section{SESSION 3 IMAGING II}

6858 OC Multiphoton tomography for tissue engineering (Invited Paper) [6858-12]

K. König, JenLab GmbH (Germany) and Univ. of the Saarland (Germany) 
$6858 \mathrm{OE}$ Optically characterizing vascular tissue constructs made with soluble versus homogenized collagen [6858-14]

D. Levitz, M. T. Hinds, N. T. Tran, S. R. Hanson, S. L. Jacques, Oregon Health \& Science Univ. (USA)

6858 OF Imaging stented tissue engineered blood vessel mimics [6858-15]

G. T. Bonnema, College of Optical Sciences, The Univ. Of Arizona (USA); K. O. Cardinal, The Univ. of Arizona (USA); S. K. Williams, Univ. of Louisville (USA); J. K. Barton, College of Optical Sciences, The Univ. of Arizona (USA) and The Univ. of Arizona (USA)

6858 OG In situ monitoring of localized shear stress and fluid flow within developing tissue constructs by Doppler optical coherence tomography [6858-16]

Y. Jia, Oregon Health \& Science Univ. (USA); P. O. Bagnaninchi, Keele Univ. (United

Kingdom); R. K. Wang, Oregon Health \& Science Univ. (USA)

\section{SESSION 4 IMAGING III}

$6858 \mathrm{OH} \quad$ Utilizing two-photon fluorescence and second harmonic generation microscopy to study human bone marrow mesenchymal stem cell morphogenesis in chitosan scaffold [6858-17]

P.-J. Su, C.-H. Huang, Y.-Y. Huang, National Taiwan Univ. (Taiwan); H.-S. Lee, National Taiwan Univ. Hospital (Taiwan); C.-Y. Dong, National Taiwan Univ. (Taiwan)

6858 Ol Determination of 3D optic axis orientation in cartilage by polarization-sensitive optical coherence tomography [6858-18]

N. Ugryumova, M. Bonesi, S. J. Matcher, Univ. of Sheffield (United Kingdom)

$68580 \mathrm{~J}$ Imaging of artificial cartilage with optical coherence tomography [6858-19]

K. Eder, R. Schmitt, Fraunhofer Institute for Production Technology (Germany);

R. Müller-Rath, RWTH Aachen (Germany)

6858 OK Application of polarization OCT in tissue engineering [6858-20]

Y. Yang, M. Ahearne, P. O. Bagnaninchi, B. Hu, K. Hampson, A. J. El Haj, School of Medicine, Keele Univ. (United Kingdom)

\section{POSTER SESSION}

$6858 \mathrm{ON}$ Availability of thiazone as an enhancer for optical clearing of skin tissue in vitro [6858-23] J. Jiang, W. Chen, Tianjin Univ. (China); R. K. Wang, Oregon Health \& Science Univ. (USA); K. XU, Tianjin Univ. (China)

685800 Correlations between second harmonic signal, microstructure, and mechanics of contracting collagen gels [6858-25]

C. B. Raub, P. D. Kim, A. J. Putnam, J. S. Lowengrub, Univ. of California, Irvine (USA);

B. J. Tromberg, Univ. of California, Irvine (USA) and Beckman Laser Institute (USA);

S. C. George, Univ. of California, Irvine (USA)

Author Index

iv 


\title{
Conference Committee
}

\author{
Symposium Chairs
}

R. Rox Anderson, Wellman Center for Photomedicine (USA), Massachusetts General Hospital (USA), and Harvard School of Medicine (USA)

James G. Fujimoto, Massachusetts Institute of Technology (USA)

Program Track Chairs

Steven L. Jacques, Oregon Health \& Science University (USA)

William P. Roach, Air Force Research Laboratory (USA)

Conference Chairs

Sean J. Kirkpatrick, Oregon Health \& Science University (USA)

Ruikang K. Wang, Oregon Health \& Science University (USA)

Program Committee

Stephen A. Boppart, University of Illinois at Urbana-Champaign (USA)

Sergio Fantini, Tufts University (USA)

Irene Georgakoudi, Tufts University (USA)

Miya Ishihara, National Defense Medical College (Japan)

Stephen J. Matcher, The University of Sheffield (United Kingdom)

Steve P. Morgan, The University of Nottingham (United Kingdom)

Ying Yang, Keele University (United Kingdom)

Session Chairs

1 Mechanics

Ruikang K. Wang, Oregon Health \& Science University (USA)

2 Imaging I

Sean J. Kirkpatrick, Oregon Health \& Science University (USA)

3 Imaging II

Miya Ishihara, National Defense Medical College (Japan)

$4 \quad$ Imaging III

Ying Yang, Keele University (United Kingdom) 
Downloaded From: https://www.spiedigitallibrary.org/conference-proceedings-of-spie on 26 Apr 2023

Terms of Use: https://www.spiedigitallibrary.org/terms-of-use 